\title{
Literature review to assemble the evidence for response scales used in patient- reported outcome measures
}

\author{
Katharine Gries ${ }^{1}$, Pamela Berry ${ }^{1}$, Magdalena Harrington ${ }^{2}$, Mabel Crescioni ${ }^{3}$, Mira Patel ${ }^{3}$, Katja Rudell ${ }^{4}$, \\ Shima Safikhani ${ }^{5}$, Sheryl Pease ${ }^{6}$ and Margaret Vernon ${ }^{5^{*}}$
}

\begin{abstract}
Background: In the development of patient-reported outcome (PRO) instruments, little documentation is provided on the justification of response scale selection. The selection of response scales is often based on the developers' preferences or therapeutic area conventions. The purpose of this literature review was to assemble evidence on the selection of response scale types, in PRO instruments. The literature search was conducted in EMBASE, MEDLINE, and PsycINFO databases. Secondary search was conducted on supplementary sources including reference lists of key articles, websites for major PRO-related working groups and consortia, and conference abstracts. Evidence on the selection of verbal rating scale (VRS), numeric rating scale (NRS), and visual analogue scale (VAS) was collated based on pre-determined categories pertinent to the development of PRO instruments: reliability, validity, and responsiveness of PRO instruments, select therapeutic areas, and optimal number of response scale options.
\end{abstract}

Results: A total of 6713 abstracts were reviewed; 186 full-text references included. There was a lack of consensus in the literature on the justification for response scale type based on the reliability, validity, and responsiveness of a PRO instrument. The type of response scale varied within the following therapeutic areas: asthma, cognition, depression, fatigue in rheumatoid arthritis, and oncology. The optimal number of response options depends on the construct, but quantitative evidence suggests that a 5-point or 6-point VRS was more informative and discriminative than fewer response options.

Conclusions: The VRS, NRS, and VAS are acceptable response scale types in the development of PRO instruments. The empirical evidence on selection of response scales was inconsistent and, therefore, more empirical evidence needs to be generated. In the development of PRO instruments, it is important to consider the measurement properties and therapeutic area and provide justification for the selection of response scale type.

Keywords: Patient-reported outcome, Response option, Response scales, Literature review

\section{Background}

Response scale selection is a critical aspect in the development of patient-reported outcome (PRO) instruments and has implications for the usability of the measure, the level of precision with which the construct of interest is measured, and the quantitative properties of the outcome score including range, standard deviation, scoring, score interpretation guidelines, and ability of the measure to detect change. Additional complicating factors

\footnotetext{
* Correspondence: Margaret.vernon@evidera.com

${ }^{5}$ Evidera, 7101 Wisconsin Ave. Suite 1400, Bethesda, MD 20814, USA Full list of author information is available at the end of the article
}

such as placement of response anchors and exact wording of anchors, cultural comparability/translatability of the format and anchor wording, and ability to migrate the scale to various modes of data collection (paper/pencil, electronic) should be examined when selecting the optimal response scale option for a PRO measure.

Despite the importance of response scale selection for PRO instruments, there is little empirical evidence for the optimal type of response scale and number of response options. For PRO measures with multiple items, 5-point and 7-point verbal rating scales (VRS) are commonly used for adult assessments; examples include the 
Patient-Reported Outcomes Measurement Information System (PROMIS) item banks and EXAcerbations of Chronic Pulmonary Disease Tool (EXACT ${ }^{\oplus}$ ). Eleven-point numeric rating scales (NRS) (particularly recommended for use in pain measurement but used in various other areas as well [1]), and $10 \mathrm{~cm} \mathrm{(cm)}$ $/ 100 \mathrm{~mm}(\mathrm{~mm})$ visual analogue scales (VAS) are commonly used for single item adult assessments. In the pediatric literature, there is some evidence that children can reliably distinguish and understand fewer response options than adults. For example, in testing the Childhood Asthma Control Test (cACT), Liu et al. [2] found that a 4-point response scale with no neutral center value was optimal. Furthermore, a graphical scale rather than a NRS or VRS may enhance comprehension of response scales in children [3].

The objective of this literature review was to assemble the evidence on the selection of response scale types to guide the development of PRO instruments. This paper focuses on the overall methodology and results of the literature review. A large body of the available evidence was specific to PRO instruments that were developed for the measure of pain or based on age of the respondent. Because of this, the results of those searches were provided in separate publications $[4,5]$.

\section{Methods}

A comprehensive review of the scientific literature was conducted to identify response scale types in the development of PRO instruments and the empirical evidence used to justify the appropriate scale type by context of use. The targeted search strategy included formal guidelines or review articles on the selection of response scales and response scale methodology (not specific to PRO instruments) and evidence on the selection of response scales for use in PRO instruments [Table 1]. Evidence was assembled and collated based on pre-determined categories: reliability, validity, and responsiveness of a PRO instrument; select therapeutic areas: asthma, cognition, depression, fatigue in rheumatoid arthritis, and oncology; and the optimal number of response scale options.

Searches were conducted in the EMBASE, MEDLINE, and PsycINFO databases. Limits were applied to include only articles published in English in the preceding 10 years (2004-2014). The duplicates across individual searches were removed prior to abstract/article review. During the full text article review and data extraction, several supplementary sources were used to identify additional relevant articles for inclusion in the review. These supplementary sources were not limited by publication date, and included the reference lists of key articles, publications not included in the search databases, and websites for major PRO-related working groups and consortia (e.g., PROMIS, NIH Toolbox, Medical Outcomes Study, Neuro-QoL, ASEQ-ME, EORTC, EuroQol Group, and FACIT Measurement System). In addition, conference abstracts were identified and reviewed from annual meetings within the preceding 2 years for Joint Statistical Meetings, Psychometric Society Meetings, International Society for Pharmacoeconomics and Outcomes Research, and International Society for Quality of Life Research. An outline of the review procedure is included in Fig. 1.

\section{Study selection}

During the review process, both abstracts and then full text publications were evaluated for eligibility by two independent reviewers. In the case of non-agreement, a third senior reviewer determined the final judgment. Articles were excluded if they provided no direct or indirect evidence relevant to the search objectives, were not applicable to PRO development, or addressed a therapeutic area not pre-specified for inclusion.

\section{Synthesis of results}

Once articles fitting the search criteria were identified, the relevant data were extracted and summarized. The extraction tables included data on the study objective, study design, study population, therapeutic area, name of PRO instrument, type of response scale, and empirical evidence for response scale selection.

Each article deemed relevant to the review and included in the extraction tables was categorized as including either direct evidence or indirect evidence. Direct evidence was defined as evidence that provided an answer specific to a research question of interest; for example, direct evidence articles compared empirically the relative robustness or merits of two different response scale types within the same study/population. Indirect evidence was defined as evidence that, while relevant to the review and the overall conclusions, does not directly answer a research question or hypothesis. For example, review articles and articles that evaluated a single response scale type within the study/population (i.e., a study evaluating comprehension of VAS in cognitively impaired patients) were considered to contain indirect evidence.

\section{Response scale types}

The most common types of response scales identified in the literature included: VAS, VRS with or without numerical anchors, NRS, and to a lesser extent graphical scales such as the Faces Scale. Several less commonly used scales were also identified, such as Likert scales and Binary scales. 
Table 1 Literature review search terms

\begin{tabular}{ll}
\hline No. Type & Search Terms \\
\hline Search \#1 & \\
$\# 1 \quad$ Consensus/ & 'consensus'/exp. OR consensus:ab,ti OR \\
& guideline/ review \\
terms & 'review'/exp. OR review:ab,ti OR 'practice \\
& guideline'/exp. OR guideline*:ab,ti OR \\
& 'expert opinion':ab,ti NOT 'institutional \\
& review board'
\end{tabular}

\#2 Response scale terms 'response scale':ab,ti OR 'response scales':ab,ti OR likert:ab,ti OR 'likert scale'/ exp. OR 'visual analog scale':ab,ti OR 'visual analog scales':ab,ti OR 'visual analogue scale':ab,ti OR 'visual analog scale'/exp. OR 'numerical rating scale':ab,ti OR 'numerical rating scales':ab,ti OR 'verbal rating scale':ab,ti OR 'verbal rating scales':ab,ti OR 'competence scale':ab,ti OR 'competence scales':ab,ti OR 'frequency scale':ab,ti OR 'frequency scales':ab,ti OR 'extent scale':ab,ti OR 'extent scales':ab,ti OR 'comparison scale':ab,ti OR 'comparison scales':ab,ti OR 'performance scale':ab,ti OR 'performance scales':ab,ti OR 'developmental scale':ab,ti OR 'developmental scales':ab,ti OR 'qualitative scale':ab,ti OR 'qualitative scales':ab,ti OR 'agreement scale':ab,ti OR 'agreement scales':ab,ti OR 'categorical scale':ab,ti OR 'categorical scales':ab,ti

\#3 Selecting terms select*:ab,ti OR choose:ab,ti OR criteria:ab,ti OR compare:ab,ti OR comparison:ab,ti

\#4 Human studies terms 'animal'/exp. NOT 'human'/exp.

\#5 Clinical trial terms 'randomized controlled trial'/exp. OR 'controlled clinical trial'/exp. OR 'clinical trial'/exp. OR 'phase 1 clinical trial'/exp. OR 'phase 2 clinical trial'/exp. OR 'phase 3 clinical trial'/exp. OR 'phase 4 clinical trial'/ exp. OR 'multicenter study'/exp. OR random*:ab,ti OR placebo:ab,ti OR trial:ab,ti OR groups:ti OR (singl*ab,ti OR doubl*:ab,ti OR trebl*:ab,ti OR trip ${ }^{*}: a b$, ti AND (mask:ab,ti OR blind*:ab,ti OR dumm*:ab,ti)) OR 'double blind procedure'/exp. OR 'single blind procedure'/exp. OR 'random allocation':ab,ti OR 'open label':ab,ti OR 'open labeled':ab,ti OR 'open labelled':ab,ti OR 'placebo'/exp. OR 'randomization'/exp. OR 'crossover procedure'/exp.

\#6 Final encompassing \#1 AND \#2 AND \#3 NOT \#4 NOT \#5 AND terms ([article]/

Search \#2

\#7 Comparison of scales TI ((scale OR measure) N5 (compare* OR terms

\#8 Merits of scales terms merit* OR evaluat* OR consider*)) OR AB ((scale OR measure) N5 (compare* OR merit* OR evaluat* OR consider*))

TI (scor* OR psychometric* OR responsive* OR "cross culture" OR "cross cultural" OR collect* OR "anchor placement" OR "data collection method" OR "internal consistency" OR "test retest" OR construct OR interrater OR standardization OR reliability $O R$ validity $O R$ sensitivity $O R$ specificity OR "item response" OR "intraclass correlation") OR AB (scor* OR psychometric* OR responsive* OR "cross culture" OR "cross cultural" OR collect* OR "anchor placement"
Table 1 Literature review search terms (Continued)

\begin{tabular}{ll}
\hline No. Type & Search Terms \\
\hline & OR "data collection method" OR "internal \\
& consistency" OR "test retest" OR construct \\
& OR interrater OR standardization OR \\
& reliability OR validity OR sensitivity OR \\
& specificity OR "item response" OR "intraclass \\
& correlation") OR SU (scor* OR psychometric* \\
& OR responsive* OR "cross culture" OR "cross \\
& cultural" OR collect* OR "anchor placement" \\
& OR "data collection method" OR "internal \\
& consistency" OR "test retest" OR construct \\
& OR interrater OR standardization OR \\
& reliability OR validity OR sensitivity OR \\
& specificity OR "item response" OR "intraclass \\
correlation")
\end{tabular}

\#9 Review/consensus terms

$\mathrm{TI}$ ("expert opinion" OR "consensus development") OR AB ("expert opinion" OR "consensus development") OR DE "Literature Review"

\#10 Final encompassing terms

\#2 AND \#7 AND \#8 NOT \#9 NOT \#4 NOT \#5 AND ([article]/lim OR [article in press]/lim OR [review]/lim) AND [english]/lim AND [2004-2014]/py

Search \#3

\#11 PRO terms

'patient satisfaction'/exp. OR (patient* NEAR/2 satisfaction):ab,ti OR (patient* NEAR/2 reported):ab,ti OR 'self report'/exp. OR (self NEAR/1 report*):ab,ti OR 'patient preference'/exp. OR (patient* NEAR/2 preference*):ab,ti OR (patient* NEAR/1 assess*):ab,ti OR 'self evaluation':ab,ti OR 'self evaluations':ab,ti OR (patient* NEAR/2 rating):ab,ti OR (patient* NEAR/2 rated):ab,ti OR 'self-completed':ab,ti OR 'selfadministered':ab,ti OR (self NEAR/1 assessment*):ab,ti OR 'self-rated':ab,ti OR 'patient based outcome'ab,ti OR 'self evaluation'/exp. OR experience*:ab,ti

\#12 Format terms

format:ab,ti OR structur*ab,ti OR ((multiple OR multi OR single OR number) NEAR/4 item*):ab,ti OR (anchor* NEAR/4 (wording OR item*)):ab,ti

\#13 Final encompassing terms

\#2 AND \#11 AND \#12 NOT \#4 AND ([article]/lim OR [article in press]/lim OR [review]/lim) AND [english]/lim AND [20042014]/py

Search \#4

\#14 Scoring/ psychometric properties

'instrumentation'/exp. OR 'validation study'/ exp. OR 'reproducibility'/exp. OR reproducib*:ab,ti OR 'psychometrics' OR psychometr*:ab,ti OR clinimetr*:ab,ti OR clinometr*ab,ti OR 'observer variation'/exp. OR observer AND variation:ab,ti OR 'discriminant analysis'/exp. OR reliab*:ab,ti OR valid*ab,ti OR coefficient:ab,ti OR 'internal consistency':ab,ti OR (cronbach*:ab,ti AND (alpha:ab,ti OR alphas:ab,ti)) OR 'item correlation':ab,ti OR 'item correlations':ab,ti OR 'item selection':ab,ti OR 'item selections':ab,ti OR 'item reduction':ab,ti OR 'item reductions':ab,ti OR agreement OR precision OR imprecision OR 'precise values' OR testretest:ab,ti OR (test:ab,ti AND retest:ab,ti) OR (reliab*:ab,ti AND (test:ab,ti OR retest:ab,ti)) 
Table 1 Literature review search terms (Continued)

\begin{tabular}{ll}
\hline No. Type & Search Terms \\
\hline & OR stability:ab,ti OR interrater:ab,ti OR 'inter
\end{tabular}

rater':ab,ti OR intrarater:ab,ti OR 'intra

rater':ab,ti OR intertester:ab,ti OR 'inter tester':ab,ti OR intratester:ab,ti OR 'intra tester':ab,ti OR interobserver:ab,ti OR 'inter observer':ab,ti OR intraobserver:ab,ti OR

'intra observer':ab,ti OR intertechnician:ab,ti OR intratechnician:ab,ti OR 'intra technician':ab,ti OR interexaminer:ab,ti OR 'inter examiner':ab,ti OR intraexaminer:ab,ti OR 'intra examiner':ab,ti OR interassay:ab,ti OR 'inter assay':ab,ti OR intraassay:ab,ti OR 'intra assay':ab,ti OR interindividual:ab,ti OR 'inter individual':ab,ti OR intraindividual:ab,ti OR 'intra individual':ab,ti OR

interparticipant:ab,ti OR 'inter participant':ab,ti OR intraparticipant:ab,ti OR 'intra participant':ab,ti OR kappa:ab,ti OR kappa's:ab,ti OR kappas:ab,ti OR 'coefficient of variation':ab,ti OR repeatab* OR (replicab* $O R$ repeated AND (measure OR measures OR findings $O R$ result $O R$ results $O R$ test $O R$ tests)) OR generaliza*:ab,ti OR

generalisa*:ab,ti OR concordance:ab,ti OR (intraclass:ab,ti AND correlation*:ab,ti) OR discriminative:ab,ti OR 'known group':ab,ti OR 'factor analysis':ab,ti OR 'factor analyses':ab,ti OR 'factor structure':ab,ti OR 'factor structures':ab,ti OR dimensionality:ab,ti OR subscale*:ab,ti OR 'multitrait scaling analysis':ab,ti OR 'multitrait scaling analyses':ab,ti OR 'item discriminant':ab,ti OR 'interscale correlation':ab,ti OR 'interscale correlations':ab,ti OR (error:ab,ti OR errors:ab,ti AND (measure*:ab,ti OR correlat*:ab,ti OR evaluat*:ab,ti OR accuracy:ab,ti OR accurate:ab,ti OR precision:ab,ti OR mean:ab,ti)) OR 'individual variability':ab,ti OR 'interval variability':ab,ti OR 'rate variability':ab,ti OR 'variability analysis':ab,ti OR (uncertainty:ab,ti AND (measurement:ab,ti OR measuring:ab,ti)) OR 'standard error of measurement':ab,ti OR sensitiv*:ab,ti OR responsive*:ab,ti OR (limit:ab,ti AND detection:ab,ti) OR 'minimal detectable concentration':ab,ti OR interpretab*:ab,ti OR (small*:ab,ti AND (real:ab,ti OR detectable:ab,ti) AND (change:ab,ti OR difference:ab,ti)) OR 'meaningful change':ab,ti OR 'minimal important change':ab,ti OR 'minimal important difference':ab,ti OR 'minimally important change':ab,ti OR 'minimally important difference':ab,ti OR 'minimal detectable change':ab,ti OR 'minimal detectable difference':ab,ti OR 'minimally detectable change':ab,ti OR 'minimally detectable difference':ab,ti OR 'minimal real change':ab,ti OR 'minimal real difference':ab,ti OR 'minimally real change':ab,ti OR 'minimally real difference':ab,ti OR 'ceiling effect':ab,ti OR 'floor effect':ab,ti OR 'item response model':ab,ti OR irt:ab,ti OR rasch:ab,ti OR 'differential item functioning':ab,ti OR dif:ab,ti OR 'computer adaptive testing':ab,ti OR 'item bank':ab,ti OR 'cross-cultural
Table 1 Literature review search terms (Continued)

\begin{tabular}{|c|c|c|}
\hline No. & Type & Search Terms \\
\hline & & equivalence':ab,ti \\
\hline \#15 & $\begin{array}{l}\text { Final encompassing } \\
\text { terms }\end{array}$ & $\begin{array}{l}\text { \#2 AND \#11 AND \#3 AND \#14 NOT \#4 AND } \\
\text { ([article]/lim OR [article in press]/lim OR } \\
\text { [review]/lim) AND [english]/lim AND [2004- } \\
\text { 2014]/py }\end{array}$ \\
\hline \multicolumn{3}{|c|}{ Search \#5 } \\
\hline$\# 16$ & RA (fatigue) terms & $\begin{array}{l}\text { 'rheumatoid arthritis'/exp./mj AND 'fatigue'/ } \\
\text { exp. OR ('rheumatoid arthritis':ab,ti AND } \\
\text { fatigue:ab,ti) }\end{array}$ \\
\hline$\# 17$ & Asthma terms & 'asthma'/exp./mj OR asthma:ab,ti \\
\hline \#18 & Cognition terms & 'cognition'/exp./mj OR cognition:ab,ti \\
\hline \#19 & Depression terms & 'depression'/exp./mj OR depression:ab,ti \\
\hline \#20 & SCLC terms & $\begin{array}{l}\text { 'lung small cell cancer'/exp./mj OR 'small } \\
\text { cell lung cancer':ab,ti }\end{array}$ \\
\hline \#21 & Pain terms & 'pain'/exp./mj OR pain:ab,ti \\
\hline \#22 & Sub-final terms & \#16 OR \#17 OR \#18 OR \#19 OR \#20 OR \#21 \\
\hline \#23 & $\begin{array}{l}\text { Final encompassing } \\
\text { terms }\end{array}$ & $\begin{array}{l}\text { \#2 AND \#11 AND \#3 AND \#22 NOT \#4 AND } \\
\text { ([article]/lim OR [article in press]/lim OR } \\
\text { [review]/lim) AND [english]/lim AND [2004- } \\
\text { 2014]/py }\end{array}$ \\
\hline
\end{tabular}

\section{Visual analogue scale}

The VAS is a scale comprised of a horizontal or vertical line, usually $10 \mathrm{~cm}(100 \mathrm{~mm})$ in length, anchored at both ends by verbal descriptors [6]. The respondent places a line perpendicular to the VAS line at the point that represents the intensity of the effect in question (e.g., pain). The length of the VAS is imperative on paper, as the score is determined using a ruler and measuring the distance between the lower anchor and the mark made by the respondent (range: 0-100). A variation of the VAS includes either numbers or adjectives indicating intensity along the scale, though this is not encouraged as the numbers and adjectives can bias the results by adding additional components to the scale that may alter interpretation.

\section{Verbal rating scale}

A VRS is a scale that consists of a list of words or phrases describing different levels of the main effect (e.g., pain), in order from least to most intense. The respondent reads the list of verbal descriptors and chooses the one that best describes the intensity of his/her experience [6]. Traditionally a VRS does not contain numbers, but the review identified many examples of VRS with numbers assigned to all or some of the verbal anchors. The study team considered VRS with numbers to be a subcategory of the VRS, with the use of numbers present for scoring purposes and/or to indicate to the respondent that the verbal anchors are meant to have equidistant intervals. Based on the results of the literature review, the VRS was also referred to as a verbal 


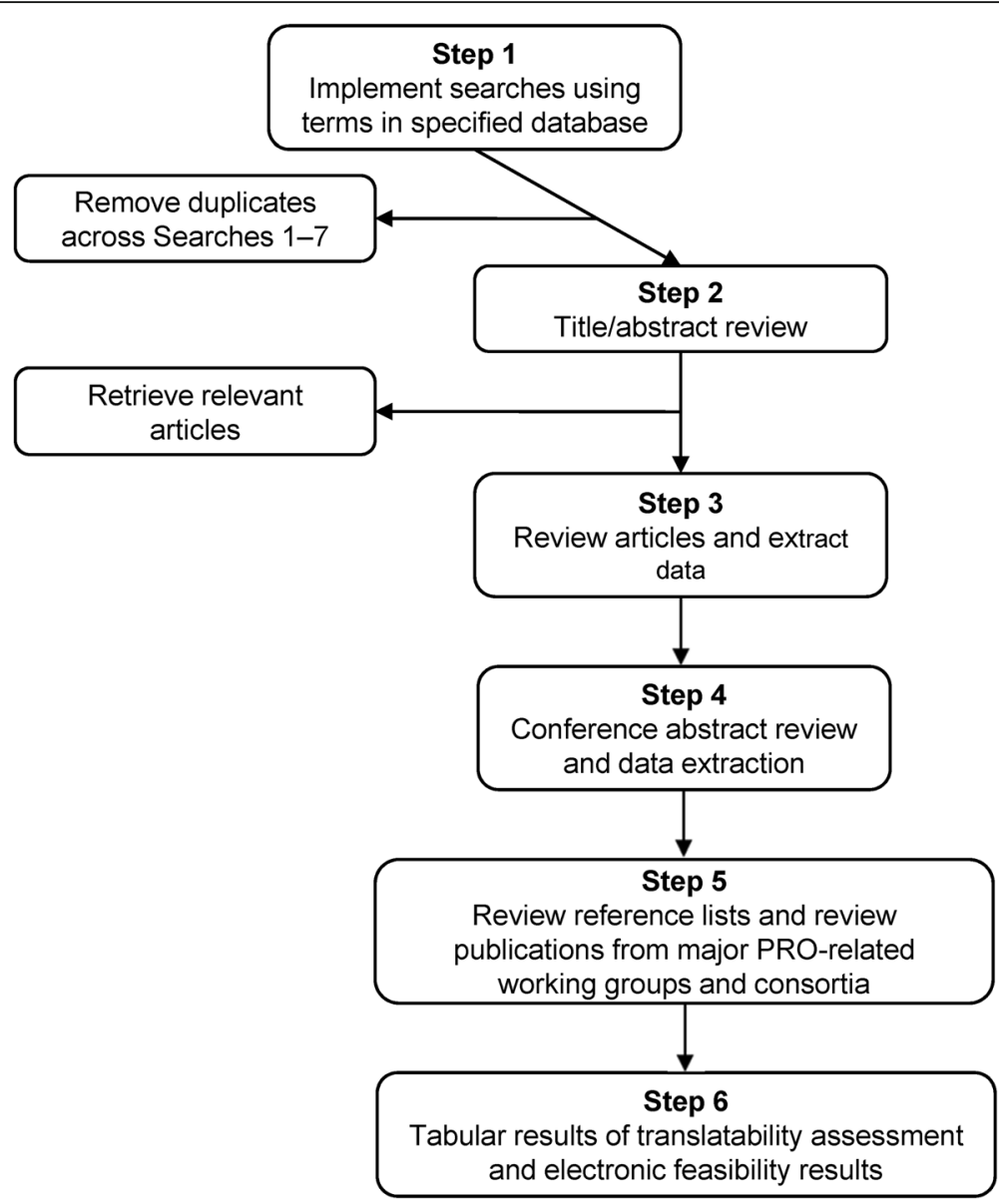

Fig. 1 Outline of search procedures and data extraction. PRO: patient-reported outcome

category scale, verbal graphic rating scale, and verbal descriptor scale; and for purposes of this report, were classified as a VRS.

\section{Numeric rating scale}

The NRS is a scale that represents an intensity continuum for respondents to rate the effect (e.g., pain) using a range of integers [6]. The most common NRS is an 11-point scale ranging from 0 (no effect) to 10 (maximal effect). The respondent selects one number that best represents the intensity being experienced. Variations of the NRS included the use of verbal anchors at various points at the middle or ends of a scale; this is common in the context of PRO instrument development.

\section{Faces scale}

A Faces scale is a type of graphical scale that uses photographs or pictures to show a continuum of facial expressions. Line drawings of faces are the most common graphic representation, as their lack of gender or ethnicity indicators makes them applicable to a wider range of respondents [6]. The respondent then selects the face that best describes how he or she is feeling. Verbal labels are usually very simple or non-existent for use in children. The Faces scale does not require reading ability or specific language, thereby facilitating pediatric and multi-cultural comprehension.

\section{Likert (Likert-type) response scale}

The Likert scale is a type of ordinal scale characterized by several features: the scale contains more than one item; response levels are arranged horizontally; response levels are anchored with consecutive integers; response levels are also anchored with verbal labels, which connote more-or-less evenly-spaced gradations; verbal labels are bivalent and symmetrical around a neutral middle; and the scale often measures attitude in terms of level of agreement/disagreement with a target statement [7]. Likert-type scales are most often used to assess agreement, attitude, and probability; while common in social psychology or health psychology scales, they have less use in health outcomes assessments [6]. One exception is a Global Impression of Change scale, where an evaluation of health is made at the start of a new treatment 
or over a specific time frame. The provision of an odd number of response categories allows respondents to choose a middle, or neutral, response. An even number of response categories forces the respondent to commit themselves to one side of the scale or the other side. The choice between odd and even response categories depends on the desirability of allowing a neutral position. One of the main differences between Likert or Likert-type scales and the VRS is the presence of the neutral middle anchor in the Likert-type scale but not in the VRS, which orders descriptors from least to most measurable attribute(s) [6].

In this literature review, response scales were frequently referred to as Likert or Likert-type; however, most of these scales did not strictly meet the requirements for a Likert scale. Thus, while many scales were referred to as Likert or Likert-type in the original publication, they were more appropriately classified as VRS, and in the literature review will be referred to as VRS.

\section{Results}

\section{Study selection}

The literature search for evidence on types of response scales in formal guidelines or review articles identified 1315 abstracts, plus 13 additional articles selected through secondary sources and 5 conference abstracts. The literature search on the selection of response scale types specific to the development of PRO instruments resulted in 5299 abstracts, 35 abstracts from secondary sources, and 46 conference abstracts. After review the number of references totaled 186 full-text articles. During abstract screening 6199 irrelevant references were excluded, then 463 full text articles were reviewed and 51 conference abstracts. Reasons for exclusion after full-text review included: no discussion or available evidence on the response scale selection $(n=233)$, duplicate $(n=36)$, clinician or observer-rated instrument $(n=5)$, full-text publication not available $(\mathrm{n}=3)$, and 48 conference abstracts were excluded for not containing enough details for data extraction. Results are presented on the selection of response scale types based on reliability, validity, responsiveness, therapeutic areas, and optimal number of response scale options. Over $40 \%$ of the included literature (77 references) discussed the selection of response scale type for the measurement of pain and based on study population; therefore, these conclusions were published separately for a comprehensive discussion on the unique issues pertaining to single item pain scales and the differences between pediatric and adult PRO instruments $[4,5]$.

\section{Synthesis of results Reliability}

Results for the selection of response scale type based on reliability of a PRO instrument were variable. A study on the pediatric population (non-specific therapeutic area) found no difference in test-retest reliability among the VRS, VAS, and a numeric VAS response scale [8]. A study in adults with rheumatoid arthritis found the NRS to be more reliable than VAS or 5-point VRS, with greater test-retest reliability in a subset of participants who were illiterate [9]. Phan and colleagues [10] also found the NRS to have superior test-retest reliability compared to VAS or 4-point VRS when assessed in adults with chronic pruritus. Test-retest reliability was greater for the VAS compared to the other two scale types in healthy adults [11]. Two studies (one on adult geriatric patients with neurological disorders; another on adults with pain) compared 5-point VRS to VAS; VAS was found to have slightly greater test-retest reliability in both studies [12, 13]. A study in adults with angina compared a 5-point VRS to NRS and found no difference in the test-retest reliability of the measure [14]. In another comparison of the NRS and VAS, a study of perceptual voice evaluation in adults for an IVR (interactive voice response) system, there was no difference in intra-rater agreement [15]. However, overall, the NRS and VAS tend to demonstrate better test-retest reliability than the VRS.

\section{Validity}

Many studies reported concurrence between the response scale types being evaluated within each study. The majority reported large correlations between different items/scales that evaluated the same concept; this is an important consideration in the validity of results compared between response scale types. Only one study in adults with angina reported on the magnitude of correlations using external criterion variables for the response scales under consideration; there was no difference between an NRS and 5-point VRS in concurrent validity [16].

\section{Responsiveness}

Results for the evaluation of these scale types based on responsiveness, or the ability of the scale to detect change in the underlying condition of a patient with treatment in a naturalistic setting, are provided in Table 2. Results for responsiveness were found only in the pain literature and, as such, may not be generalizable to other therapeutic areas. The comparative responsiveness of VRS and NRS to measure the intensity of pain in patients with chronic pain was assessed directly using two 6-point VRS (current pain) items and four 11-point NRS items from the Brief Pain Inventory (BPI; worst pain, least pain, average pain, and current pain) [17]. The 6-point VRS included the Present Pain Index (PPI) $(0=$ no pain, $1=$ mild, $2=$ discomforting, $3=$ distressing, $4=$ horrible, and $5=$ excruciating) and the 6-point 
Table 2 Key studies that support response scale selection for PRO instruments based on responsiveness

\begin{tabular}{|c|c|c|c|}
\hline Reference & Response Scale Type & $\begin{array}{l}\text { Methods to Determine } \\
\text { Responsiveness }{ }^{\mathrm{a}}\end{array}$ & Summary of Results ${ }^{b}$ \\
\hline Grotle et al. 2004 [26] & 11-point NRS VAS & SRM & $\begin{array}{l}\text { In acute pain, for improved patients } \\
\text { NRS SRM }=2.0 \text { and VAS SRM }=1.6 . \\
\text { For unchanged patients NRS SRM }=1.0 \\
\text { and VAS SRM }=-0.5 \text {. } \\
\text { In chronic pain, for improved } \\
\text { patients NRS SRM }=1.1 \text { and VAS SRM }=0.4 \text {. } \\
\text { For unchanged patients NRS SRM }=-0.2 \\
\text { and VAS SRM }=0.1 \text {. }\end{array}$ \\
\hline Skovlund et al. 2005 [27] & $\begin{array}{l}\text { VAS: } 100 \mathrm{~mm} \text { line anchored } \\
\text { at no pain/discomfort and } \\
\text { pain/discomfort 4-point VRS: } \\
\text { none, mild, moderate, severe }\end{array}$ & $\begin{array}{l}\text { Sensitivity of scales } \\
\text { with multiple simulations }\end{array}$ & $\begin{array}{l}\text { Cross-sectional analyses with } \\
\text { multiple simulations to understand } \\
\text { the sensitivity of scales. } \\
\text { The VAS consistently gave higher power } \\
\text { to detect true differences in pain ratings } \\
\text { than the 4-point VRS. }\end{array}$ \\
\hline Chanques et al. 2010 [16] & $\begin{array}{l}\text { 11-point NRS 5-point VRS } \\
\text { (no pain, mild pain, moderate } \\
\text { pain, severe pain, extreme pain) } \\
\text { VAS: } 10-\mathrm{cm} \text { line anchored at } \\
\text { no pain and extreme pain }\end{array}$ & $\begin{array}{l}\text { ES Type of ES (Cohen's d or SRM) } \\
\text { not provided in the reference }\end{array}$ & $\begin{array}{l}\text { Patients identified NRS was the easiest, } \\
\text { most accurate and preferred scale in } \\
\text { comparison with } 5 \text {-point VRS and VAS. } \\
\text { NRS demonstrated the best sensitivity } \\
(96.6 \%) \text { and negative predictive value } \\
(89.6 \%) \text { whereas VRS demonstrated } \\
\text { the best specificity }(70.7 \%) \text { and positive } \\
\text { predictive value }(86.3 \%) \text {. VAS } \\
\text { demonstrated the lowest performance, } \\
\text { except for the negative predictive value, } \\
\text { which was comparable to VRS } \\
\text { ES for } 11 \text {-point NRS: } 1.18 \\
\text { ES for 5-point VRS: } 0.94 \\
\text { ES for VAS: } 1.13 \text { (vertical orientation) }\end{array}$ \\
\hline Dogan et al. 2012 [28] & $\begin{array}{l}\text { Faces scale: } 7 \text {-point horizontal } \\
\text { scale that defines feels due to pain. } \\
\text { First face represents no pain and } \\
\text { the last face represents the worst } \\
\text { possible pain VAS: } 10-\mathrm{cm} \text { horizontal } \\
\text { line anchored at no pain and severe pain. }\end{array}$ & Calculated ES (SRM) & $\begin{array}{l}\text { Faces scale ES }=1.78 \\
\text { VAS ES }=1.36\end{array}$ \\
\hline Chien et al. 2013 [17] & $\begin{array}{l}\text { 11-point NRS (several different BPI scales) } \\
\text { 6-point VRS - PPI (no pain, mild, } \\
\text { discomforting, distressing, horrible, excruciating) } \\
\text { 6-point VRS - ODI (no pain, very } \\
\text { mild, moderate, fairly severe, } \\
\text { very severe, the worst imaginable) }\end{array}$ & SRM & $\begin{array}{l}\text { Results for all participants: } \\
11 \text {-point NRS SRM: ranged } \\
\text { from } 0.17 \text { to } 0.42 \\
\text { 6-point VRS SRM: ranged } \\
\text { from } 0.27 \text { to } 0.29\end{array}$ \\
\hline Gonzalez-Fernandez et al. 2014 [29] & $\begin{array}{l}\text { VAS ( } 100 \mathrm{~mm} \text { line) } \\
\text { NRS: (gLMS = VAS with the } \\
\text { addition of numbers) }\end{array}$ & Between group difference & $\begin{array}{l}\text { The mean (SD) VAS score } \\
\text { was } 6.13(2.27) \text { and the mean } \\
\text { (SD) NRS score (after scaling to a } \\
0-10 \text { scale) was } 4.35(2.52) \text {, with } \\
\text { medians of } 7 \text { and } 4 \text {, respectively. } \\
\text { The mean difference between the } \\
\text { two scores (VAS and NRS) was + } \\
1.78(P<0.0001) \text {. }\end{array}$ \\
\hline
\end{tabular}

$P R O$ patient-reported outcome, NRS numeric rating scale, VAS visual analogue scale, SRM standardized response mean, VRS verbal rating scale, ES effect size, $B P I$ Brief Pain Inventory, ODI Oswestry Disability Index, $g$ LMS general Labeled Magnitude Scale, SD standard deviation

${ }^{\mathrm{a}} \mathrm{SRM}$ calculated by dividing the mean change by the standard deviation of the mean change scores. Effect size of $0.2=\mathrm{small}, 0.5=$ moderate, and $>0.8=$ large clinical change

${ }^{b}$ All references provided direct evidence: Primary research that compares different response scales within study

Oswestry Disability Index (ODI) $(0=$ no pain, $1=$ very mild, $2=$ moderate, $3=$ fairly severe, $4=$ very severe, and $5=$ worst imaginable). For all participants, the standardized response mean (SRM) was small while the VRS-PPI $(0.29 ; 95 \% \mathrm{CI}: 0.17,0.41)$ and VRS-ODI $(0.27 ; 95 \% \mathrm{CI}$ : $0.15,0.38)$ were smaller than the BPI NRS measure for current pain $(0.36$; $95 \%$ CI: $0.23,0.48)$ [17]. For participants classified as responders, the BPI NRS current pain (0.89, 95\% CI: $0.70,1.07)$ exhibited large responsiveness and the VRS-PPI $(0.58 ; 95 \%$ CI: $0.40,0.77)$ and VRS-ODI (0.52; 95\% CI: 0.34, 0.70) achieved moderate responsiveness [17].

\section{Therapeutic area}

Results to support the selection of response scale type based on select therapeutic areas are provided in Table 3. A 5-point VRS used in a PRO instrument evaluating asthma was well understood and acceptable to adults and a 4-point VRS with graphics was understood by children (ages 4 through 11), based on cognitive interviews [2, 18]. Patients with cognitive impairment preferred a VRS over a VAS, but test-retest reliability was similar for both formats [13]. For depression, cognitive interviews supported use of an 11-point NRS, and a 4-point VRS was just as 
Table 3 Key studies that support response scale selection used in PRO instruments based on select therapeutic areas

\begin{tabular}{|c|c|c|c|c|}
\hline References & $\begin{array}{l}\text { Study Type, Evidence Type } \\
\text { Grade }\end{array}$ & Response Scale Type & Objective & Summary of Results \\
\hline \multicolumn{5}{|l|}{ Asthma } \\
\hline $\begin{array}{l}\text { Sherbourne et al. } 2012 \\
{[18]}\end{array}$ & $\begin{array}{l}\text { Cross-sectional } \\
\text { observational } \\
\text { study, Indirect, C }\end{array}$ & 5-point VRS & $\begin{array}{l}\text { Develop asthma-specific } \\
\text { quality of life items }\end{array}$ & $\begin{array}{l}\text { A 5-point VRS for asthma quality } \\
\text { of life assessment in } \\
\text { adults was understood based on qualitative research with } \\
\text { patients (cognitive interviews). }\end{array}$ \\
\hline Liu et al. 2007 [2] & $\begin{array}{l}\text { Cross-sectional } \\
\text { observational study, } \\
\text { Indirect, C }\end{array}$ & 4-point VRS & $\begin{array}{l}\text { Develop and validate } \\
\text { the Childhood Asthma } \\
\text { Control Test (C-ACT) }\end{array}$ & $\begin{array}{l}\text { Children between the ages of } 4 \text { and } 11 \text { could understand } \\
\text { and complete a 4-point VRS assisted by facial graphics. }\end{array}$ \\
\hline \multicolumn{5}{|l|}{ Cognition } \\
\hline $\begin{array}{l}\text { Hagell and } \\
\text { Knutsson } 2013[13]\end{array}$ & $\begin{array}{l}\text { Prospective, } \\
\text { observational } \\
\text { study, Direct, A }\end{array}$ & 5-point VRS and VAS & $\begin{array}{l}\text { Compare test-retest } \\
\text { properties of } 2 \text { general } \\
\text { health single item } \\
\text { response formats among } \\
\text { people with neurological } \\
\text { disorders }\end{array}$ & $\begin{array}{l}\text { Test-retest reliability assessments were similar for both } \\
\text { formats, however patients preferred the VRS over the VAS } \\
\text { format. }\end{array}$ \\
\hline \multicolumn{5}{|l|}{ Depression } \\
\hline Preston et al. 2011 [19] & $\begin{array}{l}\text { Cross-sectional } \\
\text { observational } \\
\text { study, Direct, A }\end{array}$ & $\begin{array}{l}\text { 4-point VRS and } \\
5 \text {-point VRS }\end{array}$ & $\begin{array}{l}\text { Evaluate the precision of the } \\
5 \text {-point VRS response scale } \\
\text { utilized in the emotional } \\
\text { distress PROMIS item bank }\end{array}$ & $\begin{array}{l}\text { The 5-point response options are not always equally } \\
\text { spaced (i.e., do not meet the assumptions of an equal } \\
\text { interval scale) and 4-point response categories were as } \\
\text { precise as five. }\end{array}$ \\
\hline Lasch et al. 2012 [30] & $\begin{array}{l}\text { Cross-sectional } \\
\text { observational study, } \\
\text { Indirect, C }\end{array}$ & 11-point NRS & $\begin{array}{l}\text { Develop a content } \\
\text { valid PRO measure } \\
\text { for Major Depressive } \\
\text { Disorder (MDD) }\end{array}$ & $\begin{array}{l}\text { Cognitive interview demonstrated that an 11-point NRS } \\
\text { was well understood and appropriate for evaluating } \\
\text { concepts. }\end{array}$ \\
\hline \multicolumn{5}{|c|}{ Rheumatoid Arthritis (Fatigue) } \\
\hline Hewlett et al. 2007 [31] & Review, Indirect, B & VAS and NRS & $\begin{array}{l}\text { Systematic literature } \\
\text { review to identify } \\
\text { fatigue in rheumatoid } \\
\text { arthritis scales; assess scale } \\
\text { measurement } \\
\text { properties }\end{array}$ & $\begin{array}{l}\text { A VAS scale was the most frequently utilized scale to } \\
\text { evaluate fatigue in rheumatoid arthritis and shows evidence } \\
\text { of validity but there was no standardized VAS scale to } \\
\text { evaluate fatigue in rheumatoid arthritis as scales were } \\
\text { study specific. NRS used to evaluate fatigue in rheumatoid } \\
\text { arthritis showed some evidence of construct validity but } \\
\text { data on criterion validity, reliability, or sensitivity were } \\
\text { not found. }\end{array}$ \\
\hline Nicklin et al. 2010 [32] & $\begin{array}{l}\text { Cross-sectional } \\
\text { observational } \\
\text { study, Direct, A }\end{array}$ & VAS and NRS & $\begin{array}{l}\text { Develop and validate } \\
\text { a patient reported } \\
\text { outcome measure of } \\
\text { fatigue in RA, the } \\
\text { Bristol RA Fatigue- } \\
\text { Multidimensional } \\
\text { Questionnaire (BRAF-MDQ) } \\
\text { and the Bristol } \\
\text { RA Fatigue (BRAF) } \\
\text { short scales (VAS/NRS) }\end{array}$ & $\begin{array}{l}\text { The final wording for fatigue severity, effect, and coping } \\
\text { VAS/NRS scales was based on focus group recommendations } \\
\text { and required measurement properties. The VAS /NRS were } \\
\text { understoodby all patients in the way they were intended by } \\
\text { the authors. Vertical orientation of the scales enhanced } \\
\text { comprehension (rather than horizontal). } \\
\text { The NRS and VAS scales were } \\
\text { correlated between } 0.68-0.78 \text {, and showed similar criterion } \\
\text { and construct validity. The NRS produced slightly higher } \\
\text { scores than the VAS and although the differences were } \\
\text { not significant, the results demonstrate the scales are not } \\
\text { interchangeable. Although the VAS and NRS performed } \\
\text { in similar ways, the NRS was selected for use in evaluating } \\
\text { fatigue in this population since some patients found the } \\
\text { VAS difficult to understand and because the NRS is easier } \\
\text { to score. }\end{array}$ \\
\hline Khanna et al. 2008 [33] & $\begin{array}{l}\text { Prospective, } \\
\text { observational } \\
\text { study, Indirect, C }\end{array}$ & VAS & $\begin{array}{l}\text { Evaluate score } \\
\text { interpretation } \\
\text { (MID) for a fatigue } \\
\text { VAS }\end{array}$ & $\begin{array}{l}\text { Mean MID estimates ranged from }-0.82 \text { to }-1.12 \text { for } \\
\text { improvement and } 1.13 \text { to } 1.26 \text { for worsening (range of } 0-10 \text { ) } \\
\text { for a fatigue VAS. These results were similar to those see } \\
\text { in RA clinical trials. }\end{array}$ \\
\hline
\end{tabular}

Oncology

Koshy et al. 2004 [34] Cross-sectional, observational study, Direct, A
VAS, VRS, Graphical rating scales
Determine patient preferences for pain assessment scale type
Most patients (56\%) preferred the pain VAS, 30\% preferred the graphical (coin) rating scale, 13\% preferred the VRS, and no patients preferred the graphical (color) scale. Findings of statistically significant positive correlations between the VAS and VRS suggest both represent similar pain intensity, and both could be used as reliable pain assessment tools. A single item VAS was recommended for evaluating pain in oncology patients because it is reliable and well understood, and preferred by most patients in this study.

Pain intensity ratings using the VAS, NRS, and VRS are highly inter-correlated. The NRS is easily understood by most patients, recommended in many pain treatment 
Table 3 Key studies that support response scale selection used in PRO instruments based on select therapeutic areas (Continued)

\begin{tabular}{|c|c|c|c|c|}
\hline References & $\begin{array}{l}\text { Study Type, Evidence Typea, } \\
\text { Grade }^{\mathrm{b}}\end{array}$ & Response Scale Type & Objective & Summary of Results \\
\hline & & & population & $\begin{array}{l}\text { guidelines, and may be more reliable than the VAS in } \\
\text { clinical trials, particularly with low literacy patients. } \\
\text { Pediatric cancer pain scales including color scales, pain } \\
\text { thermometers, and Faces scales are suitable for evaluating } \\
\text { cancer pain in children under } 5 \text { years of age. Children over } \\
\text { the age of } 5 \text { years can typically complete NRS or VAS. }\end{array}$ \\
\hline Rohan 2012 [36] & Review, Indirect, B & $\begin{array}{l}\text { VRS and 11-point } \\
\text { NRS }\end{array}$ & $\begin{array}{l}\text { Review of distress } \\
\text { screening measures } \\
\text { used in oncology }\end{array}$ & $\begin{array}{l}\text { A review of the multi-item Hospital Anxiety and Depression } \\
\text { Scale (HADS) and the Brief Symptom Inventory- } 18 \\
\text { (BSI-18) scale, and a single item Distress Thermometer } \\
\text { (11-point NRS) concluded the Distress Thermometer was as } \\
\text { discriminative as the multi-item HADS and BSI-18. }\end{array}$ \\
\hline $\begin{array}{l}\text { Sigurdardottir et al. } 2014 \\
\text { [37] }\end{array}$ & $\begin{array}{l}\text { Delphi-process, } \\
\text { Indirect, D }\end{array}$ & NRS & $\begin{array}{l}\text { Delphi process to obtain } \\
\text { consensus on a basic set } \\
\text { of core variables to describe } \\
\text { or classify a palliative } \\
\text { care cancer population }\end{array}$ & $\begin{array}{l}\text { The 11-point NRS scale was recommended to evaluate } \\
\text { important aspects of palliative care in cancer (e.g., appetite, } \\
\text { depression, anxiety) and PRO instrument selection should } \\
\text { always be undertaken with consideration of specific } \\
\text { objectives, samples, treatments, and available resources. }\end{array}$ \\
\hline King et al. 2014 [38] & $\begin{array}{l}\text { Prospective } \\
\text { observational } \\
\text { study, Direct, A }\end{array}$ & $\begin{array}{l}\text { 11-point NRS and } \\
\text { VAS }\end{array}$ & $\begin{array}{l}\text { Determine optimal } \\
\text { instrument to measure } \\
\text { subjective symptom } \\
\text { benefit in clinical } \\
\text { trials of palliative }\end{array}$ & $\begin{array}{l}\text { For an ovarian symptom PRO measure, the 11-point NRS } \\
\text { was preferable over the VAS and VRS due to improved } \\
\text { responsiveness, ease of use, and compliance. }\end{array}$ \\
\hline Jacobs et al. 2013 [39] & $\begin{array}{l}\text { Prospective } \\
\text { observational } \\
\text { study, Indirect, C }\end{array}$ & Faces scale & $\begin{array}{l}\text { Psychometric evaluation } \\
\text { of a pediatric mucositis } \\
\text { scale in cancer patients }\end{array}$ & $\begin{array}{l}\text { For a pediatric mucositis scale in cancer patients ages } \\
8 \text { to } 18 \text {, a Faces scale was found to be reliable, valid, } \\
\text { and responsive. }\end{array}$ \\
\hline Ng et al. 2012 [40] & $\begin{array}{l}\text { Cross-sectional, } \\
\text { observational } \\
\text { study, Direct, A }\end{array}$ & $\begin{array}{l}\text { VAS, NRS, and Faces } \\
\text { scales }\end{array}$ & $\begin{array}{l}\text { Investigate correlations } \\
\text { between, and patient } \\
\text { preference for, pain } \\
\text { assessment scales } \\
\text { for use in an oncology } \\
\text { population }\end{array}$ & $\begin{array}{l}\text { The VAS, NRS, and Faces scale showed a high degree of } \\
\text { association with intensity of pain making these scales } \\
\text { appropriate for pain assessment in cancer. The Faces scale } \\
\text { was preferred over the VAS and NRS and was superior to } \\
\text { the NRS or VAS with cognitively impaired patients }\end{array}$ \\
\hline Chordas et al. 2013 [41] & $\begin{array}{l}\text { Prospective } \\
\text { observational } \\
\text { study, Direct, A }\end{array}$ & $\begin{array}{l}\text { 11-point NRS, VAS, } \\
\text { VRS }\end{array}$ & $\begin{array}{l}\text { Determine if a single } \\
\text { item pain measure } \\
\text { can accurately identify } \\
\text { clinically significant } \\
\text { pain in a pediatric brain } \\
\text { cancer population }\end{array}$ & $\begin{array}{l}\text { In a pediatric population of brain cancer patients, a } \\
\text { multi-item measure with VRS was more precise than a } \\
\text { single item disease thermometer (variation of 11-point NRS). }\end{array}$ \\
\hline Banthia et al. 2006 [42] & $\begin{array}{l}\text { Prospective } \\
\text { observational } \\
\text { study, Direct, A }\end{array}$ & VAS and VRS & $\begin{array}{l}\text { Comparison of daily versus } \\
\text { weekly, unidimensional } \\
\text { versus multidimensional } \\
\text { measures of fatigue in a } \\
\text { breast cancer population }\end{array}$ & $\begin{array}{l}\text { A single item cancer fatigue VAS daily and weekly had } \\
\text { some discordance between the daily and weekly } \\
\text { measurement, indicating they are not capturing the same } \\
\text { information. The single item fatigue VAS showed greatest } \\
\text { overlap with the general fatigue subscale of the } \\
\text { multidimensional fatigue measure, suggesting the VAS } \\
\text { item is a unidimensional measure of one aspect of fatigue. } \\
\text { The decision to use a multidimensional or } \\
\text { unidimensional measures of fatigue will depend upon } \\
\text { the research question. }\end{array}$ \\
\hline Grassi et al. 2013 [43] & $\begin{array}{l}\text { Cross-sectional, } \\
\text { observational study, } \\
\text { Indirect, C }\end{array}$ & $\begin{array}{l}\text { NRS with Graphical } \\
\text { component and } \\
\text { multi-item measures }\end{array}$ & $\begin{array}{l}\text { Validation and acceptance } \\
\text { of the Distress Thermometer } \\
\text { in an Italian cancer population }\end{array}$ & $\begin{array}{l}\text { A distress thermometer (NRS with graphical component) } \\
\text { was as specific and sensitive as multi-item measures and } \\
\text { was slightly preferred by patients. }\end{array}$ \\
\hline
\end{tabular}

VRS verbal rating scale, VAS visual analogue scale, NRS numeric rating scale, $R A$ rheumatoid arthritis, $P R O$ patient-reported outcome

${ }^{a}$ Direct evidence: Primary research that compares different response scales within study. Indirect evidence: Review or expert opinion based on empirical evidence or primary research that evaluates a single response scale type within the study

bGrade Key: A) Primary research: compares different response scales within study; B) Review or expert opinion: based on an empirical evidence base; C) Primary research: evaluates a single response scale type within the study; and D) Review or expert opinion, based on expert consensus, convention, or historical evidence

precise in measurements as a 5-point VRS [19]. For fatigue in RA, the VAS and NRS were correlated but not interchangeable; meanwhile, scores from the NRS were higher than the VAS, and patients found the VAS more difficult to understand [20]. Results in oncology studies support use of an 11-point NRS, VAS, VRS, and graphical scales based on the contexts of use and study populations.

\section{Optimal number of response scale options}

Literature on the optimal number of response scale options is presented in Table 4 . In the comparison of a 5-point and 3-point VRS, there was evidence across studies that a 5-point scale was more informative and discriminative than a 3-point scale, but additional research was suggested [21]. Similarly, a 3-point scale was acceptable when compared to a 5-point scale if a simple 
scale was preferred based on the study population and construct of interest [22]. In a comparison of the 5-point VRS, 7-point VRS, and 11-point NRS scales to evaluate self-esteem, academic performance, and socioeconomic status, the 11-point NRS scale was more normally distributed than the shorter scale options, and demonstrated adequate validity; the authors therefore recommended selection of an 11-point NRS for self-reported measures used to assess social constructs [23]. An item response theory (IRT) analysis on the PROMIS items concluded that 4 to 6 was the optimal response set number; when more than 6 points were used, two or more response options were typically collapsed to improve model fit [24].

\section{Discussion}

The aim of this targeted literature review was to provide an overview of the response scale types commonly used in PRO instruments and to collate the empirical evidence for each type of scale. In the development of PRO instruments, the selection of the response scale(s) used should be based on the best available evidence.

Results for therapeutic area were limited based on the number of references provided for each disease state, thus, limiting the ability to recommend a type of response scale for a therapeutic area of interest. Empirical evidence suggests that a researcher's choice of a VAS, NRS, VRS, or Faces scale is not based on the therapeutic area but on other aspects, such as study population (age), format of response option, and the concept being measured in the PRO instrument. The optimal number of response options depends on the construct and the number of items making up the domain of measure. A 5-point or 6-point VRS was more informative and discriminative than response scales with fewer response options, and that an 11-point NRS was more normally distributed than shorter scale options [21, 23]. However, while having more response options may be appropriate when assessing symptoms, it is important to consider the size of the instrument and the burden of response for patients, particularly if you are assessing functioning or daily activity, where such measures typically ask for a large set of responses. If these measures are being used as endpoints in a clinical trial setting, note that scores may vary depending not only on the overall number of items in the measure, but also the number of options for response to each individual item.

The intention of the literature review was to provide recommendations in the selection of response scale options for the development of new PRO instruments. But because the evidence is equivocal and there are several factors that needs to be taken into consideration, it is not as easy as providing broad recommendations. But we have provided a hypothetical case example to showcase value in collating the empirical evidence.
In this hypothetical example, a new PRO instrument needs to be developed to assess change in symptoms and change in functioning after patients are treated with a new compound as part of a clinical trial. There will be approximately 20 items and the evidence suggests that the VRS, NRS, and VAS are all appropriate response scale options for consideration.

\section{a. Selection: 6-point VRS}

Justification: Empirical evidence suggest that data from an 11-point NRS was more normally distributed than a 5-point or 7-point VRS, but the developers decided to reduce the number of options given the larger number of items being asked of the subjects, therefore going with a VRS. Once the VRS and anchors were selected, the developers had to decide on the number of options, with evidence supporting anything between 4-points and 7-points. The objective was to select a scale that would discriminate between treatment arms; based on the evidence a 6-point scale showed slightly better discrimination and reliability compared to a 5-point scale and response sets of greater than 6 choices typically collapsed two or more options when scoring to improve model fit. This literature review was limited in that the key evidence was identified from articles published over the 10-year timespan from 2004 through 2014. Results were limited to a small number of studies that provided direct evidence, and multiple studies were difficult to compare given the variety in study design and diversity of terminology. The search strategy was based on pre-specified criteria that may not have been inclusive of global research using different terminology for PRO instruments. In the development of a PRO measure, the reliability, validity, and responsiveness is not only dependent on the response option, as examined in this study, but also on the item stem and concept being measured. The results of the literature review are limited to the evidence provided on only response scale variable and does not include investigation into how the psychometric properties are also related to the item stem.

Important considerations for response scale selection in PRO measures that were not addressed in the literature review include item response theory (IRT) and the use of Rasch analysis to support the type and format of response scales. IRT was not included as part of this literature review, since it was most likely not employed in older studies, which would mean there would be insufficient information to reach a valid conclusion. However, these types of analyses are now important in addressing the gaps in the literature to further assess the psychometric properties of items and their response options. 
Table 4 Key studies that support response scale selection used in PRO instruments based on optimal response set number

\begin{tabular}{|c|c|c|c|c|c|}
\hline Reference & $\begin{array}{l}\text { Response Scale } \\
\text { Type }\end{array}$ & $\begin{array}{l}\text { Study Type, Evidence } \\
\text { Type }^{a} \text {, Grade }\end{array}$ & Study Population & Summary of Results & Conclusion \\
\hline $\begin{array}{l}\text { Cleopas et al. } \\
2006[44]\end{array}$ & $\begin{array}{l}\text { Binary } \\
\text { 3-point VRS } \\
\text { 5-point VRS }\end{array}$ & $\begin{array}{l}\text { Prospective } \\
\text { study, Direct, A }\end{array}$ & $\begin{array}{l}1996 \text { adult patients } \\
\text { discharged from the } \\
\text { hospital in Switzerland }\end{array}$ & $\begin{array}{l}\text { Superior reliability, assessed } \\
\text { by Cronbach's alpha and test } \\
\text {-retest, and convergent and } \\
\text { discriminant validity for the } \\
5 \text {-point version compared } \\
\text { to the binary or 3-point } \\
\text { version in the Nottingham } \\
\text { Health Profile (NHP). }\end{array}$ & $\begin{array}{l}\text { 5-point VRS improved } \\
\text { patient acceptability, reduced } \\
\text { ceiling effects, and improved } \\
\text { measurement properties }\end{array}$ \\
\hline $\begin{array}{l}\text { DeWalt et al. } \\
2007 \text { [24] }\end{array}$ & $\begin{array}{l}\text { 4-point VRS } \\
\text { 5-point VRS } \\
\text { 6-point VRS }\end{array}$ & $\begin{array}{l}\text { Instrument } \\
\text { development } \\
\text { and/or validation } \\
\text { study, Direct, A }\end{array}$ & $\begin{array}{l}\text { Analysis of PROMIS items; } \\
\text { pain, fatigue, emotional } \\
\text { distress, physical } \\
\text { function, and social function }\end{array}$ & $\begin{array}{l}\text { Optimal response set } \\
\text { number was somewhat } \\
\text { dependent on the item } \\
\text { and construct, } 4 \text { to } 6 \\
\text { response options was } \\
\text { typically optimal because } \\
\text { this number both reduced } \\
\text { cognitive burden for } \\
\text { respondents and each } \\
\text { option could provide unique } \\
\text { information; investigators } \\
\text { found that with response } \\
\text { sets of greater than six } \\
\text { choices, two or more } \\
\text { options were typically } \\
\text { collapsed to improve } \\
\text { step-disorder and model fit. }\end{array}$ & $\begin{array}{l}\text { Based on IRT analyses } \\
\text { recommend 4-point to } \\
6 \text {-point based on the } \\
\text { item construct }\end{array}$ \\
\hline $\begin{array}{l}\text { Janssen et al. } \\
2008 \text { [45] }\end{array}$ & $\begin{array}{l}\text { 3-level } \\
\text { 5-level }\end{array}$ & $\begin{array}{l}\text { Instrument } \\
\text { development } \\
\text { and/or validation } \\
\text { study, Direct, A }\end{array}$ & $\begin{array}{l}81 \text { adult respondents } \\
\text { in a panel session }\end{array}$ & $\begin{array}{l}\text { 5-level version had higher } \\
\text { acceptability and comprehension } \\
\text { and demonstrated } \\
\text { superior reliability, } \\
\text { validity, and } \\
\text { discriminatory power. }\end{array}$ & $\begin{array}{l}\text { 5-level reduced ceiling } \\
\text { effect, increased benefit } \\
\text { in the detection of mild } \\
\text { problems and in measuring } \\
\text { general population health }\end{array}$ \\
\hline $\begin{array}{l}\text { Chomeya } \\
2010[46]\end{array}$ & $\begin{array}{l}\text { 5-point Likert } \\
\text { 6-point Likert }\end{array}$ & $\begin{array}{l}\text { Instrument } \\
\text { development } \\
\text { and/or validation } \\
\text { study, Direct, A }\end{array}$ & $\begin{array}{l}180 \text { undergraduate } \\
\text { students from } \\
\text { Mahasarakham University }\end{array}$ & $\begin{array}{l}\text { The 6-point Likert scale } \\
\text { had slightly better discrimination } \\
\text { and reliability, assessed } \\
\text { by Cronbach's alpha, } \\
\text { compared to a 5-point scale. }\end{array}$ & $\begin{array}{l}\text { Both the 5-point and 6-point } \\
\text { scales gave discrimination } \\
\text { at acceptable level per the } \\
\text { standard of psychology tests }\end{array}$ \\
\hline $\begin{array}{l}\text { Rhodes et al. } \\
2010 \text { [47] }\end{array}$ & $\begin{array}{l}\text { 5-point Likert } \\
\text { 7-point Likert }\end{array}$ & $\begin{array}{l}\text { Instrument } \\
\text { development } \\
\text { and/or validation } \\
\text { study, Direct, A }\end{array}$ & $\begin{array}{l}412 \text { volunteer students } \\
\text { in introduction psychology } \\
\text { or physical education courses. }\end{array}$ & $\begin{array}{l}\text { The 7-point scale (strongly } \\
\text { disagree, moderately disagree, } \\
\text { slightly disagree, undecided, } \\
\text { slightly agree, moderately } \\
\text { agree, strongly agree) had } \\
\text { slightly higher reliability, } \\
\text { assessed by Cronbach's alpha, } \\
\text { overall but predictive validity } \\
\text { was largely comparable to } \\
\text { the 5-point scale (strongly } \\
\text { disagree, moderately disagree, } \\
\text { undecided, agree, strongly agree). } \\
\text { The 7-point scale demonstrated } \\
\text { larger variability compared } \\
\text { to the 5-point scale. }\end{array}$ & $\begin{array}{l}\text { Either the 5-point or } \\
\text { the } 7 \text {-point scale is } \\
\text { appropriate for use in } \\
\text { scales for physical } \\
\text { activity research }\end{array}$ \\
\hline $\begin{array}{l}\text { Bakshi et al. } \\
2012 \text { [22] }\end{array}$ & $\begin{array}{l}\text { 3-point Likert } \\
\text { 5-point Likert }\end{array}$ & $\begin{array}{l}\text { Instrument } \\
\text { development } \\
\text { and/or validation } \\
\text { study, Direct, A }\end{array}$ & $\begin{array}{l}\text { Inpatients aged } 50 \text { years } \\
\text { and above in Singapore } \\
(n=579) \text {; caregivers were } \\
\text { interviewed as a patient } \\
\text { proxy if the patient } \\
\text { was not contactable, } \\
\text { too weak, or had } \\
\text { a language barrier. }\end{array}$ & $\begin{array}{l}\text { The 3-point versions } \\
\text { (disagree, neutral, and agree) } \\
\text { were comparable to the 5-point } \\
\text { versions (strongly disagree, } \\
\text { disagree, neutral, agree, and } \\
\text { strongly agree); the scores } \\
\text { performed similarly. The 3-point } \\
\text { versions were not less } \\
\text { reliable, assessed by } \\
\text { Cronbach's alpha, or } \\
\text { discriminative. }\end{array}$ & $\begin{array}{l}\text { The 3-point scale is } \\
\text { acceptable if a simple } \\
\text { scale is required }\end{array}$ \\
\hline $\begin{array}{l}\text { Leung and Xu } \\
2013 \text { [23] }\end{array}$ & $\begin{array}{l}\text { 5-point VRS } \\
\text { 7-point VRS } \\
\text { 11-point NRS }\end{array}$ & Review, Indirect, B & $\begin{array}{l}7147 \text { students } \\
\text { (age } 12 \text { to } 22 \text { years) } \\
\text { in Macau. } 795 \text { students } \\
\text { in China. } 844 \text { secondary } \\
\text { students in Macau. }\end{array}$ & $\begin{array}{l}\text { Single item measures with } \\
\text { an } 11 \text {-point scale from } 0 \text { to } \\
10 \text { are closer to normality } \\
\text { and interval scales, and } \\
\text { have construct validity } \\
\text { with major social constructs. }\end{array}$ & $\begin{array}{l}\text { The 11-point scale was } \\
\text { more normally distributed } \\
\text { than the shorter scale } \\
\text { options and had good validity. }\end{array}$ \\
\hline $\begin{array}{l}\text { Dumas et al. } \\
2013[21]\end{array}$ & $\begin{array}{l}\text { 3-point VRS } \\
\text { 5-point VRS }\end{array}$ & Review, Indirect, B & $\begin{array}{l}\text { Published literature } \\
\text { for the Scale to Assess } \\
\text { Unawareness of } \\
\text { Mental Disorder (SUMD). }\end{array}$ & $\begin{array}{l}\text { The 5-point scale was } \\
\text { more informative and } \\
\text { discriminative than a } \\
\text { 3-point scale. }\end{array}$ & $\begin{array}{l}\text { Authors state that further } \\
\text { research is required to } \\
\text { determine if a } 3 \text {-point } \\
\text { or 5-point scale should }\end{array}$ \\
\hline
\end{tabular}


Table 4 Key studies that support response scale selection used in PRO instruments based on optimal response set number (Continued)

\begin{tabular}{|c|c|c|c|c|c|}
\hline Reference & $\begin{array}{l}\text { Response Scale } \\
\text { Type }\end{array}$ & $\begin{array}{l}\text { Study Type, Evidence } \\
\text { Type }^{a} \text {, Grade }\end{array}$ & Study Population & Summary of Results & Conclusion \\
\hline & & & & & be used with the SUMD. \\
\hline $\begin{array}{l}\text { Janssen et al. } \\
2013 \text { [48] }\end{array}$ & $\begin{array}{l}\text { 3-level } \\
\text { 5-level }\end{array}$ & $\begin{array}{l}\text { Instrument } \\
\text { development } \\
\text { and/or validation } \\
\text { study, Direct, A }\end{array}$ & $\begin{array}{l}3919 \text { adults with } \\
\text { chronic conditions } \\
\text { (cardiovascular } \\
\text { disease, respiratory } \\
\text { disease, depression, } \\
\text { diabetes, liver disease, } \\
\text { personality disorders, } \\
\text { arthritis, and stroke) }\end{array}$ & $\begin{array}{l}\text { For the } 5 \text {-level system, } \\
\text { the ceiling was reduced } \\
\text { from } 20.2 \%(3 \mathrm{~L}) \text { to } 16.0 \% \\
(5 \mathrm{~L}) \text {. Absolute discriminatory } \\
\text { power (Shannon index) } \\
\text { improved considerably } \\
\text { with } 5 \mathrm{~L} \text { (mean } 1.87 \\
\text { for } 5 \mathrm{~L} \text { versus } 1.24 \text { for } 3 \mathrm{~L} \text { ), } \\
\text { and relative discriminatory } \\
\text { power (Shannon Evenness index) } \\
\text { improved slightly } \\
\text { (mean } 0.81 \text { for } 5 \mathrm{~L} \\
\text { versus } 0.78 \text { for } 3 \mathrm{~L} \text { ). } \\
\text { Convergent validity } \\
\text { with WHO-5 was } \\
\text { demonstrated and improved } \\
\text { slightly with } 5 \mathrm{~L} \text {. } \\
\text { Known-groups validity } \\
\text { was confirmed for both } \\
5 \mathrm{~L} \text { and } 3 \mathrm{~L} \text {. }\end{array}$ & $\begin{array}{l}\text { 5-level version had higher } \\
\text { acceptability and comprehension } \\
\text { and demonstrated superior } \\
\text { reliability, validity, } \\
\text { and discriminatory power. }\end{array}$ \\
\hline
\end{tabular}

$P R O$ patient-reported outcome, VRS verbal rating scale, NRS numeric rating scale

${ }^{a}$ Direct evidence: Primary research that compares different response scales within study. Indirect evidence: Review or expert opinion based on empirical evidence or primary research that evaluates a single response scale type within the study

${ }^{b}$ Grade Key: A) Primary research: compares different response scales within study; B) Review or expert opinion: based on an empirical evidence base; C) Primary research: evaluates a single response scale type within the study; and D) Review or expert opinion, based on expert consensus, convention, or historical evidence

While the literature review identified an abundance of support for the VAS, this was based on historical data and does not take into consideration the preferences of patients or regulatory agencies when PRO instruments are used as primary or key secondary endpoints in clinical trials to support labeling claims. Further, this literature review did not demonstrate that the VAS was superior to other scale types in terms of psychometric properties or responsiveness. With the publication of the FDA Guidance in 2009 [25], PRO instrument development and selection of appropriate response scales for the context of use needs to be well documented, with evidence justifying the selection. Thus, when new instruments are being developed, it is important to elicit patient feedback regarding preferences and ease of use of different response scale types.

In summary, the VRS, NRS, and VAS, can all be acceptable response scale options in PRO instruments. However, when choosing a response scale type, it is important to consider the study objective and the context of use (i.e., construct being assessed, type of study population, frequency of assessment) during the development/modification of PRO instruments along with the study design.

\section{Abbreviations}

FDA: Food and Drug Administration; IMMPACT: Initiative on Methods, Measurement, and Pain Assessment in Clinical Trials; NRS: Numeric rating scale; PRO: Patient-reported outcome; VAS: Visual analogue scale; VRS: Verbal rating scale

\section{Acknowledgements}

The authors gratefully acknowledge the managerial and logistical support provided by Theresa Hall during the completion of the overall project and these manuscripts. They thank Janet Dooley of the Evidera Editorial and Design team for her editorial and preparation assistance. In addition, they thank Sarah Mann of the PRO Consortium for her assistance to the authors with communications, and reporting of disclosures and contributions.

\section{Funding}

This project was funded by the Patient-Reported Outcome (PRO) Consortium's Measurement Projects Fund. The Measurement Projects Fund is supported by the members of the PRO Consortium (https://c-path.org/ programs/pro/). The Critical Path Institute's PRO Consortium is funded, in part, by Critical Path Public Private Partnerships Grant number U18 FD005320 from the U.S. Food and Drug Administration.

\section{Availability of data and materials}

This article is entirely based on data and materials that have been published, are publicly available (thus, accessible to any interested researcher), and appear in the References list.

\section{Other information}

In order to preserve the double-blind peer review, journal-requested information on Authors, Institutions, Funding, Competing Interests, Authors' Contributions, Authors' Information, and Acknowledgements are in the cover letter.

\section{Authors' contributions}

All the authors have agreed to be accountable for all aspects of the work, particularly for ensuring that any questions of the work's accuracy or integrity are promptly investigated and resolved. All authors have given their approval of the final version or the manuscript. Each author participated in creating drafts of the manuscript or in critical revisions. KG and SS contributed to the study concept and design: MH and SS dealt with the data acquisition; KR and MV concentrated on the analysis and data interpretation. All authors read and approved the final manuscript. 


\section{Ethics approval and consent to participate}

This article does not contain any studies with human participants or animals performed by any of the authors.

\section{Consent for publication}

Not applicable.

\section{Competing interests}

The authors declare that they have no competing interests.

\section{Publisher's Note}

Springer Nature remains neutral with regard to jurisdictional claims in published maps and institutional affiliations.

\begin{abstract}
Author details
'Janssen Global Services LLC, 700 US 202, Raritan Ave, Raritan, NJ 08869, USA. ${ }^{2}$ Shire Pharmaceuticals, 500 Shire Way, Lexington, MA 02421, USA. ${ }^{3}$ Critical Path Institute, Patient-Reported Outcome Consortium, 1730 E River Rd, Tucson, AZ 85718, USA. ${ }^{4}$ Outcomes \& Evidence, Global Health \& Value, Pfizer Ltd, Tadworth, Surrey, UK. ${ }^{5}$ Evidera, 7101 Wisconsin Ave. Suite 1400, Bethesda, MD 20814, USA. ${ }^{6}$ Pfizer Inc., NYC, NY, USA.
\end{abstract}

Received: 22 November 2017 Accepted: 19 June 2018

\section{Published online: 06 September 2018}

\section{References}

1. Dworkin, R. H., Turk, D. C., Farrar, J. T., Haythornthwaite, J. A., Jensen, M. P., Katz, N. P., Kerns, R. D., Stucki, G., Allen, R. R., Bellamy, N., Carr, D. B., Chandler, J., Cowan, P., Dionne, R., Galer, B. S., Hertz, S., Jadad, A. R., Kramer, L. D., Manning, D. C., Martin, S., McCormick, C. G., McDermott, M. P., McGrath, P., Quessy, S., Rappaport, B. A., Robbins, W., Robinson, J. P., Rothman, M., Royal, M. A., Simon, L., Stauffer, J. W., Stein, W., Tollett, J., Wernicke, J., Witter, J., \& IMMPACT. (2005). Core outcome measures for chronic pain clinical trials: Immpact recommendations. Pain, 113(1-2), 9-19. https://doi.org/10.1016/j.pain.2004.09.012.

2. Liu, A. H., Zeiger, R., Sorkness, C., Mahr, T., Ostrom, N., Burgess, S. Rosenzweig, J. C., \& Manjunath, R. (2007). Development and cross-sectiona validation of the childhood asthma control test. The Journal of Allergy and Clinical Immunology, 119(4), 817-825.

3. Matza, L. S., Patrick, D. L., Riley, A. W., Alexander, J. J., Rajmil, L., Pleil, A. M., \& Bullinger, M. (2013). Pediatric patient-reported outcome instruments for research to support medical product labeling: Report of the ispor pro good research practices for the assessment of children and adolescents task force. Value in Health, 16(4), 461-479. https://doi.org/10.1016/j.jval.2013.04.004.

4. Safikhani, S., Gries, K. S., Trudeau, J. J., Reasner, D., Rudell, K., Coons, S. J., Bush, E. N., Hanlon, J., Abraham, L., \& Vernon, M. (Under review) response scale selection in adult pain measures: Results from a literature review. Journa of Patient-Reported Outcomes. https://doi.org/10.1186/s41687-018-0053-6.

5. Naegeli, A. N., Hanlon, J., Gries, K. S., Safikhani, S., Ryden, A., Patel, M., Crescioni, M., \& Vernon, M. (Under review) literature review to characterize the empirical basis for response scale selection in pediatric populations. Journal of PatientReported Outcomes. https://doi.org/10.1186/s41687-018-0051-8.

6. Streiner, D. L., \& Norman, G. R. (2008). Health measurement scales: A practical guide to their development and use, fourth edition (Fourth ed.). New York: Oxford University Press.

7. Likert, R. A. (1952). A technique for the development of attitude scales Educational and Psychological Measurement, 12, 313-315.

8. van Laerhoven, H., van der Zaag-Loonen, H. J., \& Derkx, B. H. (2004). A comparison of likert scale and visual analogue scales as response options in children's questionnaires. Acta Paediatrica, 93(6), 830-835.

9. Ferraz, M. B., Quaresma, M. R., Aquino, L. R., Atra, E., Tugwell, P., \& Goldsmith, C. H. (1990). Reliability of pain scales in the assessment of literate and illiterate patients with rheumatoid arthritis. The Journal of Rheumatology, 17(8), 1022-1024.

10. Phan, N. Q., Blome, C., Fritz, F., Gerss, J., Reich, A., Ebata, T., Augustin, M., Szepietowski, J. C., \& Stander, S. (2012). Assessment of pruritus intensity: Prospective study on validity and reliability of the visual analogue scale, numerical rating scale and verbal rating scale in 471 patients with chronic pruritus. Acta Dermato-Venereologica, 92(5), 502-507. https://doi.org/10.2340/ 00015555-1246.
11. Grant, S., Aitchison, T., Henderson, E., Christie, J., Zare, S., McMurray, J., \& Dargie, H. (1999). A comparison of the reproducibility and the sensitivity to change of visual analogue scales, borg scales, and likert scales in normal subjects during submaximal exercise. Chest, 116(5), 1208-1217.

12. Lund, I., Lundeberg, T., Sandberg, L., Budh, C. N., Kowalski, J., \& Svensson, E. (2005). Lack of interchangeability between visual analogue and verbal rating pain scales: A cross sectional description of pain etiology groups. BMC Medical Research Methodology, 5, 31. https://doi.org/10.1186/1471-2288-5-31.

13. Hagell P, Kutsson I (2013) Single-item assessment of perceived health in neurological disorders: Verbal response categories vs. visual analog scale. Paper presented at the ISOQOL 20th annual conference, Miami, FL, October 9-12.

14. Changhe $Y$, Guanlin Y, Zhihui C, Huiyong Z, Meijuan LV, Zhe Z, Yuan M (2012) Likert or number rate scale? A comparison study on Seattle angina questionnaire. Paper presented at the ISOQOL 19th annual conference, Budapest, Hungary, October 24-27.

15. Yiu, E. M., \& Ng, C. Y. (2004). Equal appearing interval and visual analogue scaling of perceptual roughness and breathiness. Clinical Linguistics \& Phonetics, 18(3), 211-229.

16. Chanques, G., Viel, E., Constantin, J. M., Jung, B., de Lattre, S., Carr, J., Cisse, M., Lefrant, J. Y., \& Jaber, S. (2010). The measurement of pain in intensive care unit: Comparison of 5 self-report intensity scales. Pain, 151(3), 711-721. https://doi.org/10.1016/j.pain.2010.08.039.

17. Chien, C. W., Bagraith, K. S., Khan, A., Deen, M., \& Strong, J. (2013). Comparative responsiveness of verbal and numerical rating scales to measure pain intensity in patients with chronic pain. The Journal of Pain, 14(12), 1653-1662. https://doi.org/10.1016/j.jpain.2013.08.006.

18. Sherbourne C, Eberhart NK, Edelen MO, Stucky BD, Lara-Greenberg M, Sin N (2012) Development of asthma-specific quality of life items for item banking. Paper presented at the ISOQOL 19th annual conference, Budapest, Hungary, October 24-27.

19. Preston, K., Reise, S., Cai, L., \& Hays, R. D. (2011). Using the nominal response model to evaluate response category discrimination in the promis emotional distress item pools. Educational and Psychological Measurement, 71(3), 523-550.

20. Nicklin, J., Cramp, F., Kirwan, J., Urban, M., \& Hewlett, S. (2010). Collaboration with patients in the design of patient-reported outcome measures: Capturing the experience of fatigue in rheumatoid arthritis. Arthritis Care and Research, 62(11), 1552-1558.

21. Dumas, R., Baumstarck, K., Michel, P., Lancon, C., Auquier, P., \& Boyer, L. (2013). Systematic review reveals heterogeneity in the use of the scale to assess unawareness of mental disorder (sumd). Current Psychiatry Reports, 15(6), 361.

22. Bakshi, A. B., Wee, S. L., Tay, C., Wong, L. M., Leong, I. Y., Merchant, R. A., \& Luo, N. (2012). Validation of the care transition measure in multi-ethnic south-east asia in Singapore. BMC Health Services Research, 12, 256. https://doi.org/10.1186/14726963-12-256.

23. Leung, S. O., \& Xu, M. L. (2013). Single-item measures for subjective academic performance, self-esteem, and socioeconomic status. Journal of Social Service Research, 39(4), 511-520.

24. DeWalt, D., Rothrock, N., Yount, S., Stone, A. A., \& PROMIS cooperative group. (2007). Evaluation of item candidates: The promis qualitative item review. Medical Care, 45(5), S12-S21.

25. Food and Drug Administration. (2009). Guidance for industry. Patientreported outcome measures: Use in medical product development to support labeling claims. Federal Register, 74(235), 65132-65133 Available at: Https://www.Fda.Gov/downloads/drugs/guidances/ucm193282.Pdf.

26. Grotle, M., Brox, J. I., \& Vollestad, N. K. (2004). Concurrent comparison of responsiveness in pain and functional status measurements used for patients with low back pain. Spine (Phila Pa 1976), 29(21), E492-E501.

27. Skovlund, E., Bretthauer, M., Grotmol, T., Larsen, I. K., \& Hoff, G. (2005). Sensitivity of pain rating scales in an endoscopy trial. The Clinical Journal of Pain, 21(4), 292-296.

28. Dogan, S. K., Ay, S., Evcik, D., Kurtais, Y., \& Gokmen Oztuna, D. (2012). The utility of faces pain scale in a chronic musculoskeletal pain model. Pain Medicine, 13(1), 125-130. https://doi.org/10.1111/j.1526-4637.2011.01290.x.

29. Gonzalez-Fernandez, M., Ghosh, N., Ellison, T., McLeod, J. C., Pelletier, C. A., \& Williams, K. (2014). Moving beyond the limitations of the visual analog scale for measuring pain: Novel use of the general labeled magnitude scale in a clinical setting. American Journal of Physical Medicine \& Rehabilitation, 93(1), 75-81. https://doi.org/10.1097/PHM.0b013e31829e76f7.

30. Lasch, K. E., Hassan, M., Endicott, J., Piault-Luis, E. C., Locklear, J., FitzRandolph, M., Pathak, S., Hwang, S., \& Jernigan, K. (2012). Development and content validity of a patient reported outcomes measure to assess symptoms of major depressive disorder. BMC Psychiatry, 12, 34. 
31. Hewlett, S., Hehir, M., \& Kirwan, J. R. (2007). Measuring fatigue in rheumatoid arthritis: A systematic review of scales in use. Arthritis and Rheumatism, 57(3), 429-439. https://doi.org/10.1002/art.22611.

32. Nicklin, J., Cramp, F., Kirwan, J., Greenwood, R., Urban, M., \& Hewlett, S. (2010). Measuring fatigue in rheumatoid arthritis: A cross-sectional study to evaluate the Bristol rheumatoid arthritis fatigue multi-dimensional questionnaire, visual analog scales, and numerical rating scales. Arthritis Care \& Research (Hoboken), 62(11), 1559-1568. https://doi.org/10.1002/ acr.20282.

33. Khanna, D., Pope, J. E., Khanna, P. P., Maloney, M., Samedi, N., Norrie, D., Ouimet, G., \& Hays, R. D. (2008). The minimally important difference for the fatigue visual analog scale in patients with rheumatoid arthritis followed in an academic clinical practice. The Journal of Rheumatology, 35(12), 23392343. https://doi.org/10.3899/jrheum.080375.

34. Koshy, R. C., Kuriakose, R., Mathew, A., \& Chandran, N. (2004). Cancer pain intensity measurements in outpatients: Preferences and comparison of pain scales among patients, caregivers, physicians and nurses in southern India. Journal of Pain \& Palliative Care Pharmacotherapy, 18(3), 5-13.

35. Anderson, K. O. (2007). Assessment tools for the evaluation of pain in the oncology patient. Current Pain and Headache Reports, 11(4), 259-264.

36. Rohan, E. A. (2012). Removing the stress from selecting instruments: Arming social workers to take leadership in routine distress screening implementation. Journal of Psychosocial Oncology, 30(6), 667-678. https:// doi.org/10.1080/07347332.2012.721487.

37. Sigurdardottir, K. R., Kaasa, S., Rosland, J. H., Bausewein, C., Radbruch, L., Haugen, D. F., \& Prisma. (2014). The european association for palliative care basic dataset to describe a palliative care cancer population: Results from an international delphi process. Palliative Medicine, 28(6), 463-473. https:// doi.org/10.1177/0269216314521264.

38. King, M. T., Stockler, M. R., Butow, P., O'Connell, R., Voysey, M., Oza, A. M., Gillies, K., Donovan, H. S., Mercieca-Bebber, R., Martyn, J., Sjoquist, K., \& Friedlander, M. L. (2014). Development of the measure of ovarian symptoms and treatment concerns: Aiming for optimal measurement of patientreported symptom benefit with chemotherapy for symptomatic ovarian cancer. International Journal of Gynecological Cancer, 24(5), 865-873. https:// doi.org/10.1097/IGC.0000000000000167.

39. Jacobs, S., Baggott, C., Agarwal, R., Hesser, T., Schechter, T., Judd, P., Tomlinson, D., Beyene, J., \& Sung, L. (2013). Validation of the children's international mucositis evaluation scale (chimes) in paediatric cancer and sct. British Journal of Cancer, 109(10), 2515-2522. https://doi.org/10.1038/bjc.2013.618.

40. Ng, A. W. Y. (2012). A cross sectional study of use of different pain assessment tools in chinese cancer patients. Journal of Pain Management, 5(1), 83-91.

41. Chordas, C., Manley, P., Merport Modest, A., Chen, B., Liptak, C., \& Recklitis, C. J. (2013). Screening for pain in pediatric brain tumor survivors using the pain thermometer. Journal of Pediatric Oncology Nursing, 30(5), 249-259. https://doi.org/10.1177/1043454213493507.

42. Banthia, R., Malcarne, V. L., Roesch, S. C., Ko, C. M., Greenbergs, H. L., Varni, J. W., \& Sadler, G. R. (2006). Correspondence between daily and weekly fatigue reports in breast cancer survivors. Journal of Behavioral Medicine, 29(3), 269279. https://doi.org/10.1007/s10865-006-9053-8.

43. Grassi, L., Johansen, C., Annunziata, M. A., Capovilla, E., Costantini, A., Gritti, P., Torta, R., Bellani, M., \& Italian Society of Psycho-Oncology Distress Thermometer Study G. (2013). Screening for distress in cancer patients: A multicenter, nationwide study in Italy. Cancer, 119(9), 1714-1721. https://doi.org/10.1002/ cncr.27902.

44. Cleopas, A., Kolly, V., \& Perneger, T. V. (2006). Longer response scales improved the acceptability and performance of the Nottingham health profile. Journal of Clinical Epidemiology, 59(11), 1183-1190. https://doi.org/10. 1016/j.jclinepi.2006.02.014.

45. Janssen, M. F., Birnie, E., Haagsma, J. A., \& Bonsel, G. J. (2008). Comparing the standard eq-5d three-level system with a five-level version. Value in Health, 11(2), 275-284. https://doi.org/10.1111/j.1524-4733.2007.00230.x.

46. Chomeya, R. (2010). Quality of psychology test between likert scale 5 and 6 points. Journal of Social Sciences, 6(3), 399-403. https://doi.org/10.3844/jssp. 2010.399.403.
47. Rhodes, R. E., Matheson, D. H., \& Mark, R. (2010). Evaluation of social cognitive scaling response options in the physical activity domain. Measurement in Physical Education and Exercise Science, 14(3), 137-150. https://doi.org/10.1080/1091367X.2010.495539.

48. Janssen, M. F., Pickard, A. S., Golicki, D., Gudex, C., Niewada, M., Scalone, L., Swinburn, P., \& Busschbach, J. (2013). Measurement properties of the eq-5d-5l compared to the eq-5d-3l across eight patient groups: A multi-country study. Quality of Life Research, 22(7), 1717-1727. https:// doi.org/10.1007/s11136-012-0322-4.

\section{Submit your manuscript to a SpringerOpen ${ }^{\circ}$ journal and benefit from:}

- Convenient online submission

- Rigorous peer review

- Open access: articles freely available online

- High visibility within the field

- Retaining the copyright to your article

Submit your next manuscript at $\boldsymbol{\sim}$ springeropen.com 